\title{
PEMANFAATAN LIMBAH KARUNG PLASTIK
}

\author{
Budiawan Sulaeman ${ }^{1)}$ \\ 1) Dosen Fakultas Teknik Universitas Andi Djemma Palopo \\ 1) budiawan@ftunanda.co.id
}

\begin{abstract}
Abstrak
Bahan baku dasar karung plastik adalah polipropilena yang kuat terhadap kerusakan yang timbul dari bahan kimia (asam dan basa) maupun fisika (panas, dingin dan tekanan). Bila dibandingkan dengan serat sintesis fiber. Polipropilena lebih kesat dan lebih mengikat bahan. Dengan dasar tersebut, Karung plastik bisa digunakan untuk pengganti serat penguat (serat fiber) pada fiberglass. Sehingga penulis tertarik untuk mengganti bahan tersebut dengan limbah karung plastik bekas yang banyak terbuang/menjadi sampah di pasar rakyat Kota Palopo. Fiberglass yang menggunakan serat polipropilena mempunyai kualitas hampir sama dengan yang menggunakan serat fiber. Uji lentur serat fiber sebesar $881,3 \mathrm{~kg} / \mathrm{cm}^{2}$ dan uji lentur serat Polipropilena mencapai $746,4 \mathrm{~kg} / \mathrm{cm}^{2}$. Uji kepadatan material dengan menggunakan serat polipropilena yang berlebihan $\left(0,20 \mathrm{~g} / \mathrm{cm}^{2}\right)$ akan menurunkan kepadatan hingga 45,14\% dari bahan uji kontrol. Sehingga komposisi kepadatannya mencapai $1,27 \mathrm{~g} / \mathrm{cm}^{2}$ tidak layak untuk digunakan sebagai bahan baku untuk meningkatkan mutu produk. Perlu diteliti ulang tentang pembuatan fiberglass dengan Serat Polipropilena, dengan menggunakan bahan baku alternatif serat yang lain (Karung Goni). Pembuatan fiberglass masih perlu dilakukan eksperimen yang lebih banyak variasi campuran dengan Serat Polipropilena guna memperoleh hasil penelitian yang lebih sempurna (penggunaan teknik sulam). Jika akan dimanfaatkan sebagai campuran fiberglass secara massal perlu ada penambahan zat pewarna seperti pigmen, sehingga hasil produk mempunyai warna yang menarik.
\end{abstract}

Kata Kunci: Fiberglass, Polipropilena, dan Karung Plastik

\section{PENDAHULUAN}

Teknologi fiberglass ataupun komposit sebenarnya sudah ada sejak zaman Mesir Kuno, yaitu digunakan untuk membuat dekorasi dan diaplikasikan pada kerajinan tembikar. Sejak saat itu, perkembangan material komposit terus berkembang. Pada tahun 1932, ditemukan material fiberglass pertama yang berkualitas baik, hasil penelitian oleh Deel Kleist yang dinamakancorning glass. Pada tahun 1935, corning glass diteliti lebih lanjut oleh seorang peneliti bernama Owen Illinois yang bertujuan untuk meningkatkan kualitas dan kekuatan dari material tersebut. Pada tahun 1936, material ini dipatenkan dengan nama fiberglass. Akhirnya, pada tahun 1938 terjadilah kerjasama antara Dael Kleist dan Owen Illinois dengan membentuk suatu perusahaan bersama bernama Corning-Owens. Dari hasil penelitian yang dilakukan oleh mereka, diketahui bahwa material ini cukup ringan dan memiliki kekuatan yang cukup baik. Material fiberglass memiliki kekuatan jauh lebih kuat bila dibandingkan dengan baja untuk berat yang sama.

Pada tahun 1942, salah seorang pegawai di perusahaan Corning-Owens yang bernama Ray Green, berhasil memproduksi kapal pertama dari bahan komposit dengan perpaduan polyester resin yang lebih dikenal dengan nama Fiberglass Reinforce Plastic (FRP) Boat. Setelah Ray Green menciptakan kapal berbahan FRP pertama, banyak bermunculan pengikut lain yang menghasilkan kapal berbahan FRP, diantaranya B.B. Swan yang menciptakan Fiberglass Catboat dengan ukuran kecil pada tahun 1947. Hampir seluruh negara di dunia pada saat ini mengadaptasi teknologi fiberglass sebagai bahan material pembuatan bangunan kapal. Karakteristiknya yang unik dan berbeda dengan material lainnya, seperti kayu ataupun logam, membuatnya menjadi salah satu pilihan dalam proses pembuatan bangunan kapal, terutama pada kapal dengan ukuran panjang kapal kurang dari $30 \mathrm{~m}$. 
Pemakaian fiberglass sebagai material bangunan kapal memeliki beberapa keuntungan antara lain: (a) Memiliki nilai atau kemampuan apung yang lebih besar bila dibandingkan dengan material lain, seperti kayu ataupun baja, dikarenakan memiliki massa jenis yang kecil. (b) Daya serap air yang kecil bila dibandingkan dengan kayu ataupun logam. (c) Pemeliharaan dan reparasi sangat mudah. (d) Tidak memerlukan pengecatan karena warna atau pigmen telah dicampurkan pada bahan gelcoat pada saat proses laminasi.

Penggunaan fiberglass, saat ini tidak hanya digunakan sebagai bahan baku pembuatan kapal atau boat. Tetapi kini meramba kepada kerajianan tangan dan berbagai produk misalnya galon air, westafel, bacttab, hasil produksi/ bidang panjat dinding, dasboard mobil dan lain - lain. Disisi lain penggunan bahan baku serat sintesis fiber (salah satu bahan inti) atau biasa disebut serat kaca dengan nama pasaran mett / roving sangatlah mahal dan dan sampai saat ini masih diimpor dari luar negeri, sehingga pembuatan atau hasil produksi dari berbagai jenis barang berbahan fiber melambung jauh/ sangat mahal.

Pasar rakyat Pasar Niaga Palopo (PNP) yang terletak di Jalan Mangga Kelurahan Tompotikka Kecamatan Wara Kota Palopo dan Pasar Andi Tadda yang terletak di Jalan Andi Tadda Kelurahan Amassangan Kecamatan Wara Utara Kota Palopo diresmikan Tanggal 21 November 2007, oleh Bapak Walikota Palopo (Drs. H. A.P. Tenriadjeng, M.Si). Sejak kedua Pasar tersebut beroprasi, banyak menghasilkan sampah/limbah, menurut data Dinas Kebersihan dan Pertamanan Kota Palopo sampah di tempat tersebut meningkat setiap tahunnya mencapai $8,3 \%$ dari tahun sebelumnya dan 6,3\% adalah sampah karung plastik, salah satunya adalah karung bekas tempat hasil bumi seperti sanyur mayur, beras, palawija, dan lain sebagainya yang di perjual belikan di pasar tersebut.
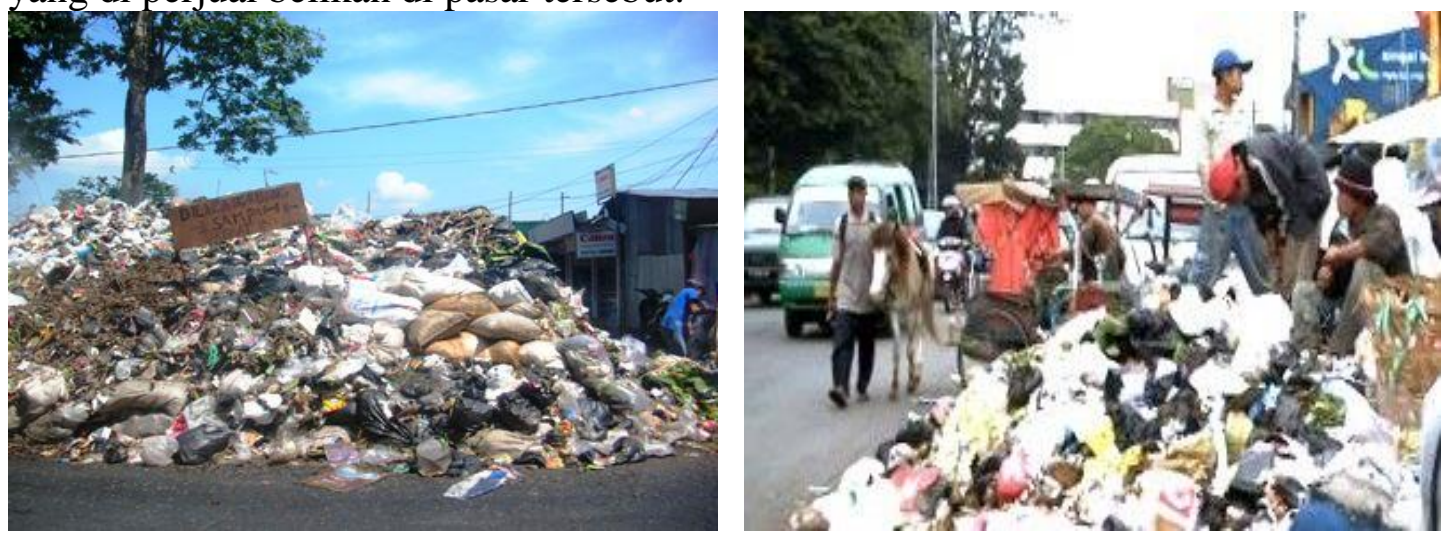

Gambar 1. Salah satu sudut Pasar Niaga Palopo (PNP) Kota Palopo dan Salah satu sudut Andi Tadda di Kota Palopo 2013

Apabila ada karung yang rusak/robek, karung tersebut dibuang begitu saja oleh pengusaha atau pedagang yang menggunakannya. Hal ini dapat menjadi salah satu masalah pencemaran terhadap pencemaran lingkungan. Karung plastik bekas akan menimbulkan bau yang tidak enak, dapat menjadi sumber penyakit dan dapat mengganggu pernapasan bagi orang menderita alergi. Bahan baku dasar karung plastik adalah Polipropilena yang kuat, tangguh dan ringan. Komponen khusus Polipropilena sangat kuat terhadap kerusakan yang timbul dari bahan kimia (asam dan basa) maupun fisika (panas, dingin dan tekanan). Bila dibandingkan dengan serat sintesis fiber. Polipropilena lebih kesat dan lebih mengikat bahan. Dengan dasar 
tersebut, Karung plastik bisa digunakan untuk penganti serat penguat (serat fiber) pada fiberglass. Sehingga penulis tertarik untuk mengganti bahan tersebut dengan limbah karung plastik bekas yang banyak terbuang/ menjadi sampah di pasar rakyat Kota Palopo. Berdasarkan fanomena diatas maka penulis mengambil judul "Pemanfaatan Limbah Karung Plastik" Tujuan dari penulisan ini bagaimana memanfaatkan limbah karung plastik sebagai alternative pengganti serat sintesis fiberglass.

Bahan dasar fiberglass adalah Resin, juga mencakup banyak sekali zat sintetis sifat mekanik yang sama (cairan kental yang mengeras menjadi padatan transparan), serta shellacs serangga dari super famili Coccoidea. Senyawa cairan lain yang ditemukan dalam tanaman atau memancarkan oleh tanaman, seperti getah, lateks, atau lendir, kadang-kadang rancu dengan resin, akan tetapi secara kimiawi tidak sama. Resin tidak larut dalam air, sebagian larut dalam alkohol, minyak esensial, eter dan minyak lemak panas, dan melembutkan dan meleleh di bawah pengaruh panas, tidak mampu sublimasi, dan terbakar dengan nyala terang tapi berasap. Contoh asam resin adalah asam abietic (asam sylvic), $\mathrm{C} 20 \mathrm{H} 30 \mathrm{O} 2$, asam plicatic terkandung dalam cedar, dan asam pimaric, $\mathrm{C} 20 \mathrm{H} 30 \mathrm{O} 2$, merupakan konstituen dari resin galipot. Asam Abietic juga dapat diekstraksi dari rosin dengan cara alkohol panas, akan mengkristal dalam selebaran, dan oksidasi menghasilkan asam trimelitat, asam isoftalat dan asam terebic. Asam Pimaric mirip asam abietic yang dilaluinya ketika suling dalam ruang hampa, ini seharusnya terdiri dari tiga isomer. Katalis, adalah suatu zat yang mempercepat laju reaksi reaksi kimia pada suhu tertentu, tanpa mengalami perubahan atau terpakai oleh reaksi itu sendiri. Suatu katalis berperan dalam reaksi tapi bukan sebagai pereaksi ataupun produk. Katalisis merupakan proses yang terjadi akibat adanya peran dari katalis. Katalis merupakan senyawa kimia yang dapat mempercepat reaksi tanpa perubahan bentuk/struktur dari katalis tersebut. Cara kerjanya yaitu dengan menempel pada bagian subtrat tertentu dan pada akhirnya dapat menurunkan energi pengaktifan dari reaksi, sehingga reaksi berlangsung dengan cepat. Katalis dapat dibedakan ke dalam dua golongan utama: (a) Katalis heterogen adalah katalis yang ada dalam fase berbeda dengan pereaksi dalam reaksi yang dikatalisinya, (b) Katalis homogen berada dalam fase yang sama. Satu contoh sederhana untuk katalisis heterogen yaitu bahwa katalis menyediakan suatu permukaan di mana pereaksi-pereaksi (atau substrat) untuk sementara terjerap. Ikatan dalam substrat-substrat menjadi lemah sedemikian sehingga memadai terbentuknya produk baru. Katalis homogen umumnya bereaksi dengan satu atau lebih pereaksi untuk membentuk suatu perantara kimia yang selanjutnya bereaksi membentuk produk akhir reaksi, dalam suatu proses yang memulihkan katalisnya. Berikut ini merupakan skema umum reaksi katalitik, di mana $\mathrm{C}$ melambangkan katalisnya:

$$
\begin{aligned}
& \mathrm{A}+\mathrm{C} \rightarrow \mathrm{AC}(1) \\
& \mathrm{B}+\mathrm{AC} \rightarrow \mathrm{AB}+\mathrm{C}(2)
\end{aligned}
$$

Meskipun katalis (C) termakan oleh reaksi 1, namun selanjutnya dihasilkan kembali oleh reaksi 2 , sehingga untuk reaksi keseluruhannya menjadi,

$$
\mathrm{A}+\mathrm{B}+\mathrm{C} \rightarrow \mathrm{AB}+\mathrm{C}
$$

katalis tidak termakan atau pun tercipta. Enzim adalah biokatalis.

Karung plastik (woven bags) merupakan kemasan berwujud kantong yang merupakan hasil anyaman berbentuk melingkar (circular weaved Polypropylene). Karung plastik merupakan pengganti karung goni yang semula digunakan untuk mengemas berbagai bahan baku / hasil bumi. Karena berbahan ringan dan lebih tahan 
terhadap air dibandingkan goni, karung plastik dalam kurun waktu singkat telah menggantikan fungsi karung goni di berbagai jenis usaha produksi,Karung plastik berbahan dasar Polipropilena. Polipropilena pertama kali dipolimerisasikan oleh $D r$. Karl Rehn di Hoechst AG, Jerman, pada 1951, yang tidak menyadari pentingnya penemuan itu. Ditemukan kembali pada 11 Maret 1954 oleh Giulio Natta, Polipropilena pada awalnya diyakini lebih murah daripada polietilena. Polipropilena atau polipropena (PP) adalah sebuah polimer termo-plastik yang dibuat oleh industri kimia dan digunakan dalam berbagai aplikasi, diantaranya pengemasan, tekstil (contohnya tali, pakaian dalam termal, dan karpet), alat tulis, berbagai tipe wadah terpakaikan ulang serta bagian plastik, perlengkapan labolatorium, pengeras suara, komponen otomotif, dan uang kertas polimer. Polimer adisi yang terbuat dari propilena monomer, permukaannya tidak rata serta memiliki sifat resistan yang tidak biasa terhadap kebanyakan pelarut kimia, basa dan asam.

Sifat-sifat kimia dan fisik, polipropilena komersial merupakan isotaktik dan memiliki kristalinitas tingkat menengah di antara polietilena berdensitas rendah dengan polietilena berdensitas tinggi; modulus Youngnya juga menengah. Melalui penggabungan partikel karet, PP bisa dibuat menjadi liat serta fleksibel, bahkan di suhu yang rendah. Hal ini membolehkan polipropilena digunakan sebagai pengganti berbagai plastik teknik, seperti ABS. Polipropilena memiliki permukaan yang tak rata, seringkali lebih kaku daripada beberapa plastik yang lain, lumayan ekonomis, dan bisa dibuat translusen (bening) saat tak berwarna tapi tidak setransparan polistirena, akrilik maupun plastik tertentu lainnya. Bisa bula dibuat buram dan/atau berwarna-warni melalui penggunaan pigmen, Polipropilena memiliki resistensi yang sangat bagus terhadap kelelahan (bahan). Polipropilena memiliki titik lebur $\sim 160{ }^{\circ} \mathrm{C}$ $\left(320^{\circ} \mathrm{F}\right)$, sebagaimana yang ditentukan Differential Scanning Calorimetry (DSC).MFR (Melt Flow Rate) maupun MFI (Melt Flow Index) merupakan suatu indikasi berat molekulnya PP serta menentukan seberapa mudahnya bahan mentah yang meleleh akan mengalir saat pengolahan berlangsung.

Sintesis, Konsep yang penting untuk memahami hubungan antara struktur polipropilena dengan sifat-sifatnya adalah taktisitas. Orientasi relatifnya setiap gugus metil $\left(\mathrm{CH}_{3}\right.$ dalam gambar) yang dibandingkan dengan gugus metil di berbagai monomer yang berdekatan punya efek yang kuat pada kemampuan polimer yang sudah jadi untuk membentuk kristal, sebab tiap gugus metil memakan tempat serta membatasi pelenturan/pelentukan tulang punggung (backbone bending).

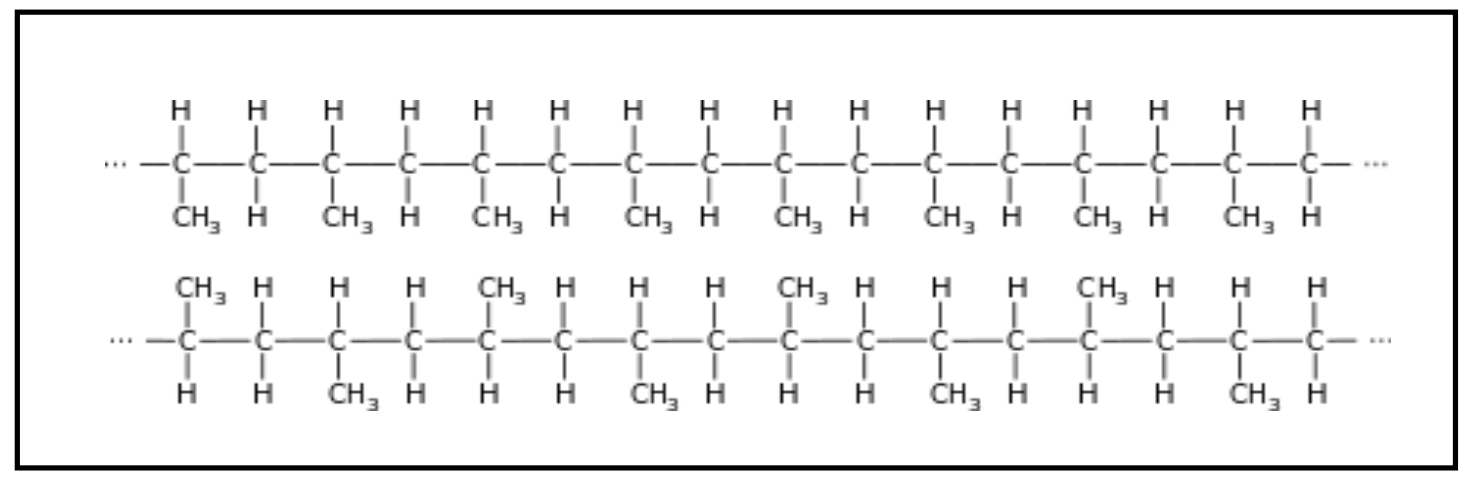

Gambar 2. Ruas-ruas pendeknya polipropilena, menunjukkan berbagai contoh isotaktik (atas) dan taktisitas sindiotaktik (bawa) 
Seperti kebanyakan polimer vinil yang lain, polipropilena yang berguna tak bisa dihasilkan oleh polimerisasi radikal dikarenakan lebih tingginya reaktivitas hidrogen alilik (yang mengarah ke dimerisasi) selama polimerisasi. Bahan yang dihasilkan dari proses itu akan memiliki gugus metil yang tersusun acak, yang disebut PP ataktik. Kurangnya benah jangkau panjang mencegah apapun kristalinitas di dalam bahan seperti itu, menghasilkan sebuah bahan amorf berkekuatan sangat kecil.

Katalis Ziegler-Natta mampu membatasi berbagai monomer mendatang ke sebuah orientasi yang spesifik, hanya menambahkan monomer-monomer itu ke rantai polimer jika mereka menghadap ke arah yang benar. Polipropilena yang paling tersedia secara komersil dibuat dengan katalis Ziegler-Natta, yang menghasilkan polipropilena yang pada umumnya isotaktik (lantai sebelah atas dalam gambar di atas). Dengan gugus metil konsisten di satu sisi, molekul seperti itu cenderung melingkar ke dalam bentuk heliks; heliks-heliks ini lalu berjajar bersebelahan untuk membentuk kristal yang memberikan sifat-sifat yang dinginkan dari sebuah polipropilena komersial.

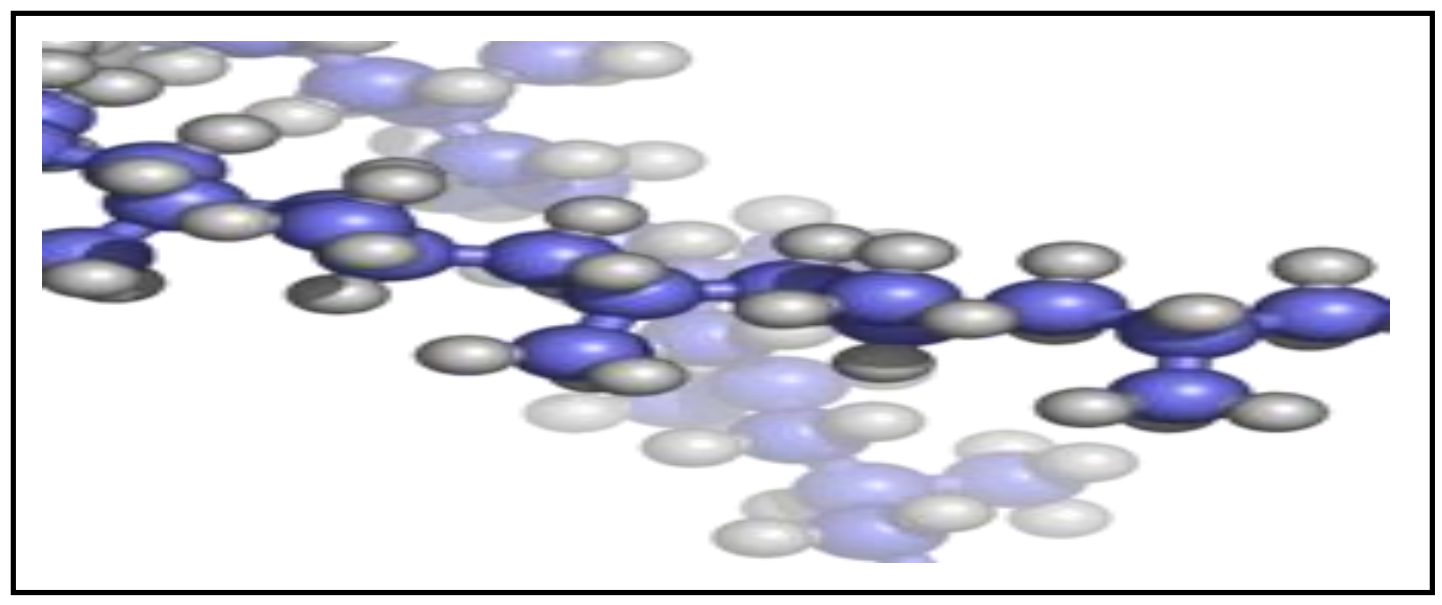

Gambar 3. Sebuah model bola-dan-rantingnya polipropilena

Katalis Kaminsky yang terekayasa dengan lebih presisi menawarkan tingkat kendali yang lebih besar. Didasarkan pada molekul metalosena, katalis ini menggunakan gugus organik untuk mengendalikan monomer yang ditambahkan, sehingga pilihan katalis yang lebih tepat mampu menghasilkan polipropilena yang isotaktik, sindiotaktik, atau ataktik, atau bahkan kombinasi dari ketiga sifat tersebut. Selain kontrol kualitatif tadi, katalis Kaminsky membolehkan kontrol kuantitatif yang lebih baik, dengan jauh lebih baiknya rasio taktisitas yang diinginkan daripada teknik Ziegler-Natta sebelumnya. Katalis ini menghasilkan pula distribusi berat molekul yang lebih sempit daripada katalis Ziegler-Natta yang tradisional, yang mampu meningkatkan berbagai sifat lebih jauh lagi.

Untuk menghasilkan polipropilena yang elastis, katalis yang menghasilkan polipropilena isotaktik bisa dibuat, tapi dengan gugus organik yang memengaruhi taktisitas yang ditahan di tempat oleh sebuah ikatan yang relatif lemah. Setelah katalis menghasilkan polimer pendek yang mampu berkristalisasi, cahaya dengan frekuensi yang tepat digunakan untuk memecahkan ikatan yang lemah ini, serta menghilangkan selektivitas katalis sehingga panjang rantai yang tersisa adalah ataktik. Hasilnya adalah bahan yang pada umumnya amorf dengan kristal-kristal 
kecil tersisip di dalamnya. Karena salah satu ujung dari tiap rantai berada di dalam sebuah kristal sedang sebagian besar panjangnya berada dalam bentuk amorf dan lunak, maka wilayah kristalin punya kegunaan yang sama dengan vulkanisasi.

Teknik mencetak atau casting dibagi menjadi dua macam yaitu (a) Teknik Mencetak Hancur adalah negative cetakan hanya dapat digunakan sekali saja pada proses mencetak. Karena pada teknik ini untuk mengambil atau melepaskan hasil cetakan harus dengan jalan menghancurkan negative cetakan. Bahan fiberglass yang kering akan kaku dan kuat, apalagi jika bentuk detail yang rumit. Jika kita tidak memaksa untuk tidak merusak negatif cetakan, meskipun dibuka dengan penuh kehati-hatian tetap saja negatif cetakan akan hancur atau rusak. Sebab teknik mencetak dengan menggunakan bahan gibs atau tanah liat sebagai bahan negatif cetakan, apabila proses kimiawi fiberglass telah selesai (mengeras) maka negatif cetakan harus dihancurkan untuk mengambil produk dari hasil cetak. Dan kadang proses cetakan hancur ini digunakan bila membuat produk hanya dengan satu model saja. (b) Teknik Cetak Ulang, cetakan dapat digunakan berulang-ulang kali untuk mendapatkan hasil cetakan. Karena bahan negatif cetakan yang sifatnya lentur memungkinkan untuk melakukan pengisian fiberglass yang berbentuk cair dan bila proses kimiawi telah berlangsung (fiberglass mengeras) maka cetakan dapat dilepas dengan mudah. Pada teknik cetak ulang bahan yang digunakan untuk membuat cetakan adalah bahan silikon yang sifat dasarnya kuat dan lentur.Memang untuk membuat cetakan negatif dengan berbahan dasar silikon kita harus mengeluarkan modal yang cukup lumayan karena harganya agak mahal.Bila kita ingin memproduksi dalam jumlah banyak, menggunakan bahan dasar silikon sebenarnya lebih ekonomis dan lebih efektif karena dengan menggunakan silikon dapat menjangkau bentuk detail atau relief yang sangat rumit.

Bahan baku cetakan adalah bahan yang digunakan untuk menahan adonan fiberglass sampai mengering. Bahan baku ini terdiri dari (a) Mirror Glass, Bahan ini mirip stemplet, pelicin lantai atau mentega. Berfungsi sebagai pelicin pada tahap pencetakan dilakukan, agar antara cetakan dan hasil cetak tidak saling merekat, sehingga hengan mudah untuk dilepas.(b) Silicone Rubber, berbentuk cair agak kental berwarna putih mirip lem kayu.Silicone rubber berguna untuk membuat cetakan dengan model yang agak rumit atau model yang kecil-kecil. (c) Tanah Liat adalah media yang dibuat sebagai model seperti apa yang kita inginkan misalnya relief atau permukaan fiberglass. Karena pada dasarnya tanah liat mudah untuk dibentuk, dapat mengeras pada waktu tertentu dan media ini dapat pula dihancurkan apabila fiberglass yang telah kita buat telah mengeras. (d) Multipleks, tripleks lapis yang terbuat dari bahan kayu dan digunakan sebagai mall untuk pembuatan sisi samping dan pembatas (ukuran) hasil produksi yang akan diproduksi/ dibuat.

\section{HASIL DAN PEMBAHASAN}

Dalam penelitian penggunaan Karung Plastik / Polipropilena sebagai bahan pengganti serat fiber pada pembuatan fiberglass digunakan analisis data secara statistik, yaitu analisis data dengan menggambarkan kualitas fiberglass secara umum yang disajikan dalam bentuk tabel maupun grafik yang mengacuh pada Standar Nasional Indonesia (SNI). Nomor 03 - 1027 - 2006 Lembaran serat semen rata yang terdiri dari (a) bentuk dan sifat tampak, (b) ukuran lembaran, (c) Kesikuan, (d) Kuat lentur, (e) Kedap air dan (f) Kepadatan (density). Pengujian material/ Bahan Uji dilakukan di laboratorium Uji Material Teknik Sipil Universitas andi Djemma 
Palopo. Adapun sampel yang digunakan dalam penelitian yang ditarik oleh peneliti dengan mengunakan metode analisis data deskriptif SNI, dengan ukuran dimensi sebagai berikut;

Tabel 1. Komposisi Bahan Uji

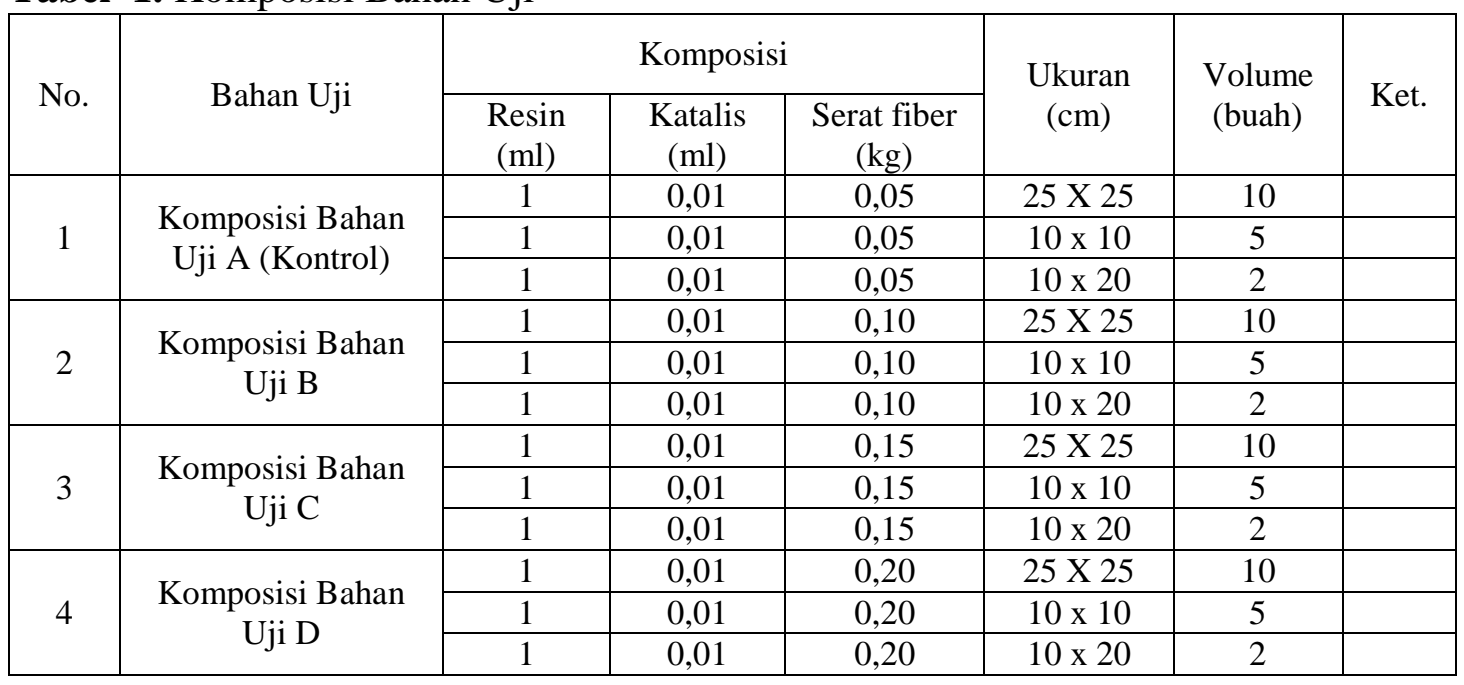

a) Hasil Pengujian Fiberglass

Hasil pengujian secara visual terhadap tepi potong dan permukaan lembaran fiberglass dapat dilihat pada tabel berikut:

Tabel 2. Bentuk dan Sifat Tampak Pada Lembaran Fiberglass

\begin{tabular}{|c|c|c|c|c|c|c|}
\hline \multirow{2}{*}{ No. } & \multirow{2}{*}{ Benda Uji } & \multirow{2}{*}{ Permukaan } & \multicolumn{4}{|c|}{ Tepi Potong } \\
\cline { 4 - 6 } & & & Sisi 1 & Sisi 2 & Sisi 3 & Sisi 4 \\
\hline 1 & A & Baik & Rata & Rata & Rata & Rata \\
\hline 2 & B & Baik & Rata & Rata & Rata & Rata \\
\hline 3 & C & Baik & Rata & Rata & Rata & Rata \\
\hline 4 & D & Baik & Rata & Rata & Rata & Kurang rata \\
\hline
\end{tabular}

Menurut SNI Nomor 03 - 1027 - 2006 bahwa lembaran serat krisotil semen rata harus mempunyai tepi potong yang lurus, rata dan mempunyai permukaan halus tidak menunjukkan retak-retak atau cacat lainnya. Dari hasil di atas dapat dilihat bahwa benda uji yang telah dipotong-potong sesuai ukuran semua sisinya rata, karena sebelum diukur dan dilakukan pengikisan bahan uji menggunakan mesin gerinda potong dengan $\varnothing 52 \mathrm{~mm}$. Dari tampak permukaan lembaran terlihat halus dan tidak menunjukkan adanya retakan atau cacat lain, walaupun ada benda uji disalah satu sisinya kurang rata karena penggunaan serat Polipropilena yang berlebihan. Dari hasil pengamatan dengan menggunakan paramater rata - rata maka benda uji tersebut layak untuk diuji dilabaratorium.

b) Pengukuran panjang dan lebar

Tabel 3. Pengukuran panjang dan lebar benda uji

\begin{tabular}{|c|c|c|c|c|c|c|}
\hline \multirow{2}{*}{ No. } & \multirow{2}{*}{\multicolumn{3}{|c|}{ Nama Bahan Uji }} & \multicolumn{2}{|c|}{ Rata - Rata (cm) } & \multirow{2}{*}{ Keterangan } \\
\hline & & & & $\mathbf{P}$ & $\mathbf{L}$ & \\
\hline \multirow{3}{*}{1} & \multirow{3}{*}{$\begin{array}{l}\text { Bahan } \\
\text { (Kontrol) }\end{array}$} & \multirow{3}{*}{$\mathrm{Uji}$} & \multirow{3}{*}{ A } & 25,0 & 24,9 & Uji Lentur \\
\hline & & & & 10,0 & 9,9 & Uji Kedap Air \\
\hline & & & & 20,0 & 10,0 & Uji Kepadatan \\
\hline 2 & Bahan Uji & & & 24,9 & 24,8 & Uji Lentur \\
\hline
\end{tabular}




\begin{tabular}{|c|c|c|c|l|}
\cline { 3 - 5 } & \multirow{4}{*}{3} & 9,9 & 9,8 & Uji Kedap Air \\
\cline { 3 - 5 } & \multirow{3}{*}{ Bahan Uji C } & 19,9 & 9,9 & Uji Kepadatan \\
\hline \multirow{3}{*}{4} & \multirow{3}{*}{ Bahan Uji D } & 24,9 & 24,8 & Uji Lentur \\
\cline { 3 - 5 } & & 9,9 & 9,7 & Uji Kedap Air \\
\cline { 3 - 5 } & & 19,8 & 9,9 & Uji Kepadatan \\
\hline & & 24,8 & 24,8 & Uji Lentur \\
\cline { 3 - 5 } & 9,8 & 9,7 & Uji Kedap Air \\
\hline & & 19,7 & 9,7 & Uji Kepadatan \\
\hline
\end{tabular}

Nilai rata-rata tertinggi yang didapat dalam pengukuran panjang dan lebar rata - rata, komposisi A (kontrol) 25,00 $\mathrm{cm}$ pada panjang dan 24,90 $\mathrm{cm}$ pada lebar (Bahan Uji Lentur), 10,00 cm X 9,9 cm (Bahan Uji Kedap Air) dan 20,00 cm X 10,00 cm (bahan Uji Kepadatan), sedangkan nilai terendah adalah bahan uji D dari komposisi pengggunaan Serat Polipropilena 0,20 Kg yaitu 24,8 cm X 24,8 cm (Bahan Uji Lentur), 9,8 cm X 9,7 cm (Bahan Uji Kedap Air) dan 19,7 X 9,7 cm (bahan Uji Kepadatan). Pada saat pemotongan benda uji harus diperhatikan, mata potong mesin yang mengikis/ menyanyat benda uji agar tidak terlalu masuk kedalam sehingga dapat mengurangi ukuran bahan uji. Dari data yang didapat dilapangan terdapat kekurangan ukuran sebesar $1-3 \mathrm{~mm}$. Menurut SNI Nomor $03-1027-2006$ bahwa penyimpangan dari panjang dan lebar fiberglass $\pm 0,3 \%=3 \mathrm{~mm}$ dari pengukuran panjang dan lebar, sehingga dapat diambil asumsi bahwa untuk benda uji dapat dipergunakan.

\section{c) Pengukuran Tebal}

Menurut SNI Nomor 03 - 1027 - 2006 bahwa penyimpangan dari tebal fiberglass maksimal $10 \%=0,6 \mathrm{~mm}$, dari hasil pengukuran tebal fiberglass menunjukkan, hasil rata-rata tebal fiberglass dari semua komposisi semuanya baik, karena tidak ada yang melebihi ketetapan.

Tabel 4. Pengukuran tebal benda uji

\begin{tabular}{|c|c|c|c|c|}
\hline No. & $\begin{array}{c}\text { Nama } \\
\text { Bahan Uji }\end{array}$ & $\begin{array}{c}\text { Rata - Rata } \\
\quad(\mathrm{cm})\end{array}$ & $\begin{array}{c}\text { Toleransi } \\
(\%)\end{array}$ & Keterangan \\
\hline \multirow{3}{*}{1} & \multirow{3}{*}{$\begin{array}{c}\text { Bahan Uji A } \\
\text { (Kontrol) }\end{array}$} & 5,95 & 0,83 & Uji Lentur \\
\hline & & 5,99 & 0,17 & Uji Kedap Air \\
\hline & & 5,98 & 0,42 & Uji Kepadatan \\
\hline \multirow{3}{*}{2} & \multirow{3}{*}{ Bahan Uji B } & 5,84 & 2,75 & Uji Lentur \\
\hline & & 5,84 & 2,67 & Uji Kedap Air \\
\hline & & 5,78 & 3,75 & Uji Kepadatan \\
\hline \multirow{3}{*}{3} & \multirow{3}{*}{ Bahan Uji C } & 5,87 & 2,25 & Uji Lentur \\
\hline & & 5,86 & 2,33 & Uji Kedap Air \\
\hline & & 5,83 & 2,92 & Uji Kepadatan \\
\hline \multirow{3}{*}{4} & \multirow{3}{*}{ Bahan Uji D } & 5,94 & 1,08 & Uji Lentur \\
\hline & & 5,93 & 1,17 & Uji Kedap Air \\
\hline & & 5,98 & 0,42 & Uji Kepadatan \\
\hline
\end{tabular}

Nilai rata-rata tertinggi yang didapat dalam pengukuran tebal yaitu komposisi A (kontrol) yaitu 5,99 mm (Bahan Uji Kedap Air), sedangkan nilai terendah yaitu dari komposisi pengggunaan Serat Polipropilenadengan komposisi 0,15 Kg dengantebal 
5,83. Dari hasil grafik di bawah maka dapat disimpulkan bahwa semakin banyak Serat Polipropilena maka semakin tebal hasil fiberglass. Hasil pengukuran tebal ratarata pada masing-masing komposisi campuran fiberglass dapat digrafikkan sebagai berikut:

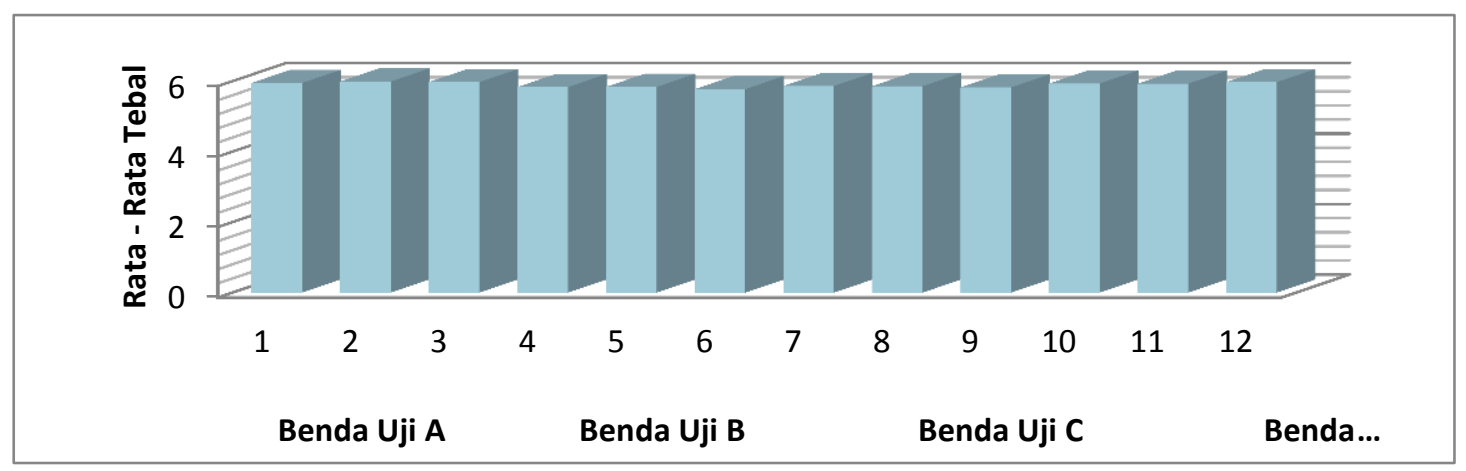

Gambar 4. Grafik Pengukuran Tebal (cm) Pada Fiberglass.

d) Kesikuan

Sisi lembaran serat krisotil semenrata / fiber yang satu terhadap yang lainnya harus siku selisi antara dua diagonalnya tidak boleh lebih dari 0,25\% dari diagonal terpendek. Dengan menggunakan rumus sebagai berikut:

Tabel 6. Kesikuan Benda Uji

$$
\text { Kesikuan }=\frac{\text { Selisih dua diagonal }}{\text { Diagonal terpendek }} \times 100 \%
$$

\begin{tabular}{|c|c|c|c|}
\hline \multirow{2}{*}{ No. } & \multirow{2}{*}{ Nama Bahan Uji } & $\begin{array}{c}\text { Rata - Rata Kesikuan } \\
(\mathbf{\%})\end{array}$ & Keterangan \\
\hline \multirow{3}{*}{1} & \multirow{3}{*}{$\begin{array}{c}\text { Bahan Uji A } \\
\text { (Kontrol) }\end{array}$} & 0,00471 & Uji Lentur \\
\cline { 3 - 4 } & \multirow{3}{*}{2} & 0,00863 & Uji Kedap Air \\
\cline { 3 - 4 } & \multirow{3}{*}{ Bahan Uji B } & 0,00449 & Uji Kepadatan \\
\cline { 3 - 4 } & & 0,00601 & Uji Lentur \\
\hline \multirow{3}{*}{3} & \multirow{3}{*}{ Bahan Uji C } & 0,01240 & Uji Kedap Air \\
\cline { 3 - 4 } & & 0,00682 & Uji Kepadatan \\
\cline { 3 - 4 } & & 0,00472 & Uji Lentur \\
\hline \multirow{3}{*}{4} & \multirow{3}{*}{ Bahan Uji D } & 0,01395 & Uji Kedap Air \\
\cline { 3 - 4 } & & 0,00683 & Uji Lentur \\
\cline { 3 - 4 } & & 0,00575 & Uji Kedap Air \\
\cline { 3 - 4 } & & 0,01846 & Uji Kepadatan \\
\hline
\end{tabular}

Nilai kesikuan rata-rata tertinggi diperoleh pada komposisi komposisi 200 gram Serat Polipropilena benda uji kepadatan yaitu $0,00457 \%$ dan nilai terendah yaitu rata-rata sebesar $0,01846 \%$. SNI $03-1027$ - 2006 menyatakan diagonal tidak boleh melebihi 0,25\% dari diagonal terpendek, sedangkan hasil yang diolah dilapangan menyatakan bahwa benda uji layak untuk digunakan karena < dari 0,25\% dari diagonal terpendek. Hasil pengukuran kesikuan rata-rata pada masing-masing komposisi campuran fiberglass dapat digrafikkan sebagai berikut: 


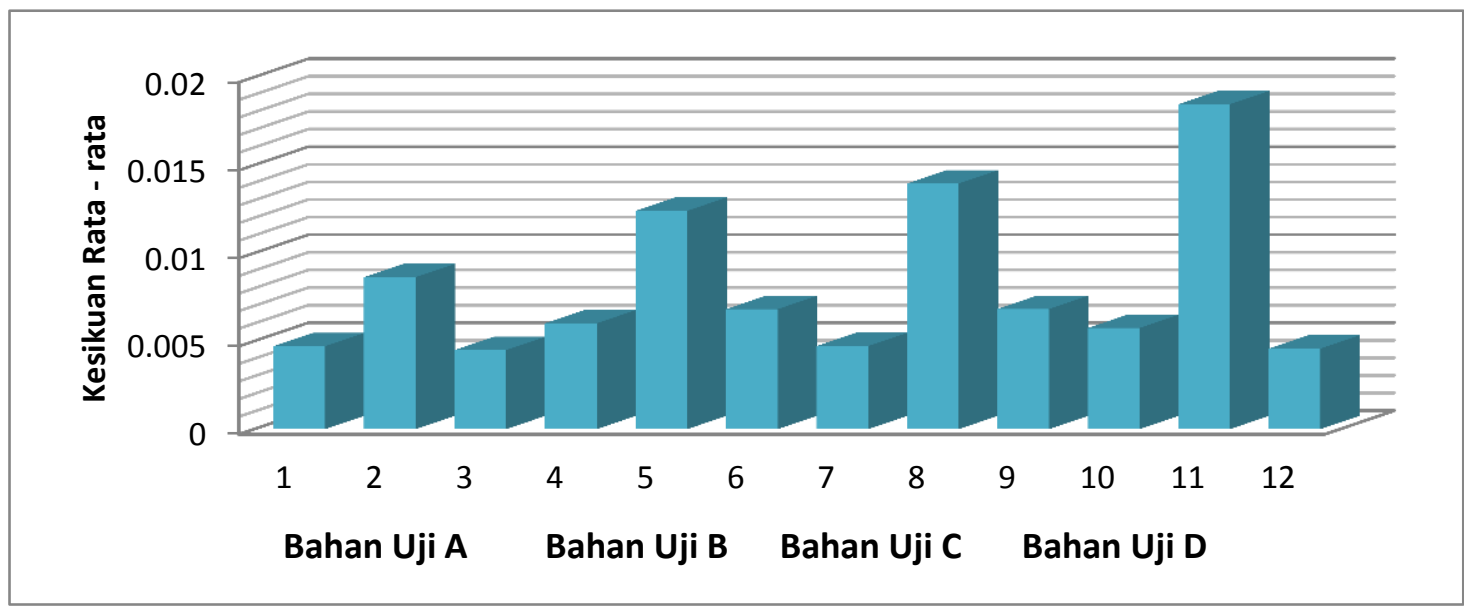

Gambar 5. Grafik Kesikuan rata - rata Pada Fiberglass.

e) Kuat Lentur

Dari hasil uji laboratorium uji material teknik mesin Politeknik Negeri Ujung Pandang, kuat lentur rata-rata pada masing-masing komposisi campuran fiberglass adalah sebagai berikut:

Tabel 6. Uji Kuat Lentur

\begin{tabular}{|c|c|c|c|c|}
\hline No. & Nama Bahan Uji & $\begin{array}{c}\text { Rata }- \text { Rata } \\
\left(\mathbf{K g} / \mathbf{c m}^{2}\right)\end{array}$ & Persentase (\%) & Keterangan \\
\hline 1 & Bahan Uji 1 (Kontrol) & 811,3 & 0 & Kontrol \\
\hline 2 & Bahan Uji 2 & 580,3 & 28,47 & Turun \\
\hline 3 & Bahan Uji 3 & 676,8 & 16,57 & Turun \\
\hline 4 & Bahan Uji 4 & 746,4 & 7,99 & Turun \\
\hline
\end{tabular}

Hasil uji tekan laboratorium diatas menunjukkan uji kuat lentur material yang paling besar adalah bahan uij A (control) campuran 1:0,01ml dan 0,05 gram serat fiber dan yang paling terendah $580 \mathrm{Kg} / \mathrm{cm} 2$ adalah bahan uji B campuran $1: 0,01 \mathrm{ml}$ dan 0,05 gram serat Polipropilena (serat karung bekas). Hal ini menunjukkan bahwa penggunaan serat Polipropilena akan menambah kualitas kuat lentur material fiberglas, kuat lentur rata - rata material tidak boleh kurang dati $130 \mathrm{Kg} / \mathrm{cm}^{2}$. Sedangkan material dengan menggunakan serat polipropilena uji kuat lenturnya mencapai $580,3-746,4 \mathrm{Kg} / \mathrm{cm}^{2}$. Adapun kenaikan dan penurunan uji kuat lentur sebagai berikut. 


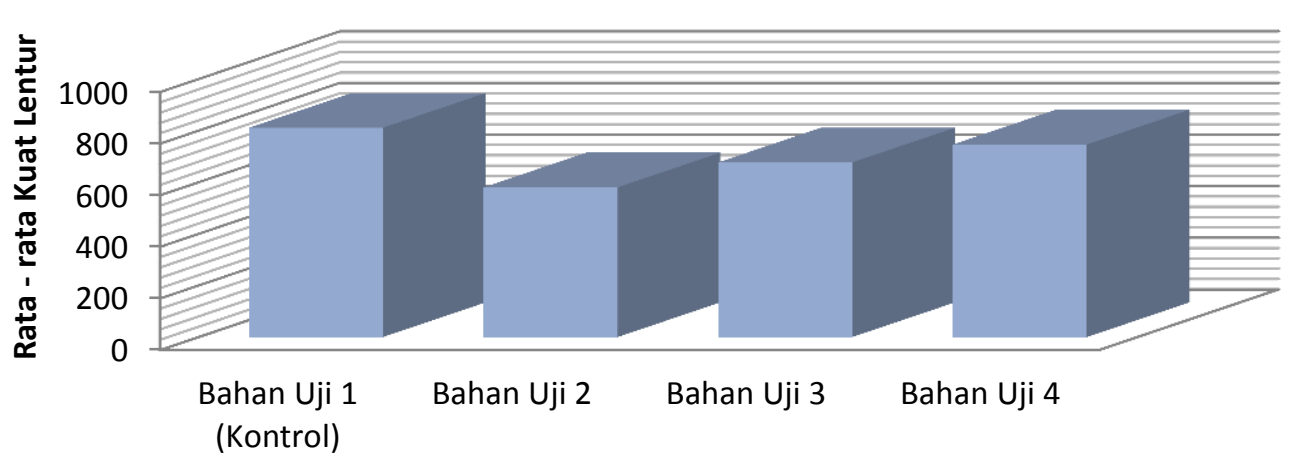

Gambar 6. Grafik Uji Kuat Lentur Pada Fiberglass.

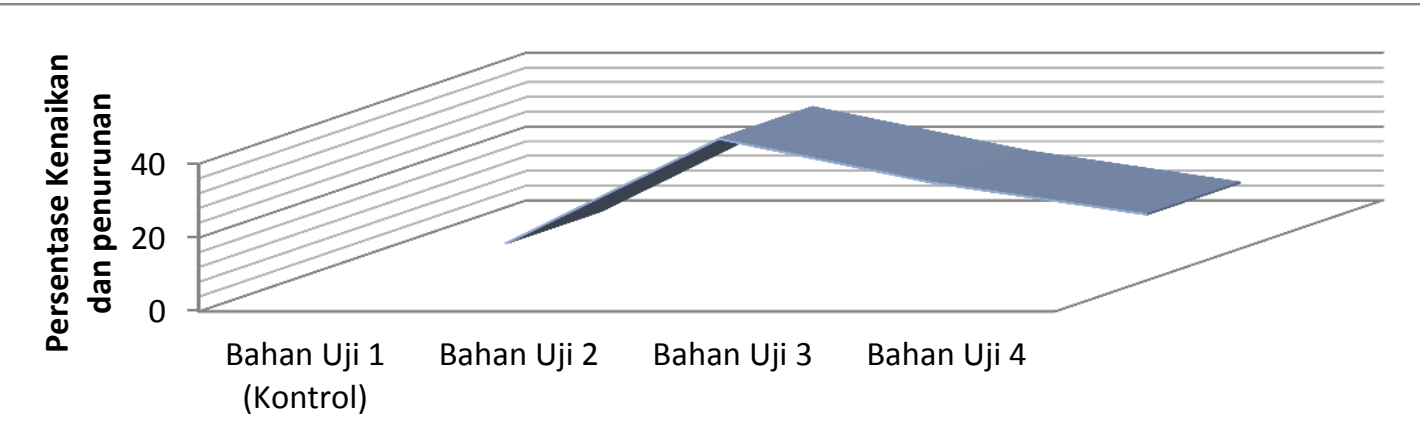

Gambar 7. Grafik Persentase kenaikan dan penurunan uji kuat lentur.

f) Kedap Air

Hasil pengamatan kedap air terhadap rembesan pada masing-masing komposisi campuran benda uji dapat ditabelkan sebagai berikut:

Tabel 7. Hasil Pengamatan Kedap Air

\begin{tabular}{|c|c|c|c|c|c|}
\hline \multirow{2}{*}{ No. } & \multirow{2}{*}{ Kedap Air } & \multicolumn{4}{|c|}{ Komposisi } \\
\cline { 3 - 6 } & A (Kontrol) & B & C & D \\
\hline 1 & $\begin{array}{c}\text { Baik (tidak } \\
\text { menetes) }\end{array}$ & Baik & Baik & Baik & Baik \\
\hline 2 & Menetes & - & - & - & - \\
\hline
\end{tabular}

Dari hasil pengamatan yang dilakukan secara visual dari semua benda uji dengan ukuran 10 x 10 tidak terjadi kebocoran antara sisi atas dan sisi bagian bawa sehingga material dinyatakan layak dalam pengujian kedap air dengan beracuan pada SNI 03 1027 - 2006 lembaran serat krisotil semen rata.

g) Kepadatan (Density)

Dari hasilperhitungankepadatan (Density) rata-rata pada masing-masing komposisi campuran fiberglass dapat dapat dilhat pada tabel berikut:

Tabel 8. Hasil pengukuran kepadatan benda uji

\begin{tabular}{|c|c|c|c|c|}
\hline No. & Nama Bahan Uji & Kepadatan $\left(\mathbf{g} / \mathbf{c m}^{2}\right)$ & Persentase (\%) & Keterangan \\
\hline 1 & Bahan Uji A & 2,31 & 0 & Kontrol \\
\hline
\end{tabular}




\begin{tabular}{|c|l|l|l|l|}
\hline 2 & Bahan Uji B & 1,95 & 15,59 & Turun \\
\hline 3 & Bahan Uji C & 1,60 & 30,60 & Turun \\
\hline 4 & Bahan Uji D & 1,27 & 45,14 & Turun \\
\hline
\end{tabular}

Hasil pengukuran kepadatan benda uji di laboratorium, menunjukkan uji kepadatan material yang paling besar adalah bahan uij A (control) dan yang paling terendah $1,27 \mathrm{~g} / \mathrm{cm}^{2}$ adalah bahan uji $\mathrm{D}$, ini menunjukkan bahwa penggunaan serat Polipropilena yang berlebihan akan mengurangi kualitas kepadatan material fiberglas, kepadatan rata - rata material tidak boleh kurang dari $1,30 \mathrm{~g} / \mathrm{cm}^{2}$. Sedangkan material dengan menggunakan serat polipropilena yang berlebihan $(0,20$ $\mathrm{g} / \mathrm{cm}^{2}$ ) uji kepadatannya menurun hingga $45,14 \%$ dari bahan uji kontrol. Sehingga komposisi D tidak layak untuk digunakan sebagai bahan baku untuk meningkatkan mutu produk, karena lebih rendah dari mutu produk yang ditetapkan oleh SNI Nomor 03 - 1027 - 2006 Lembaran serat krisotil semen rata.

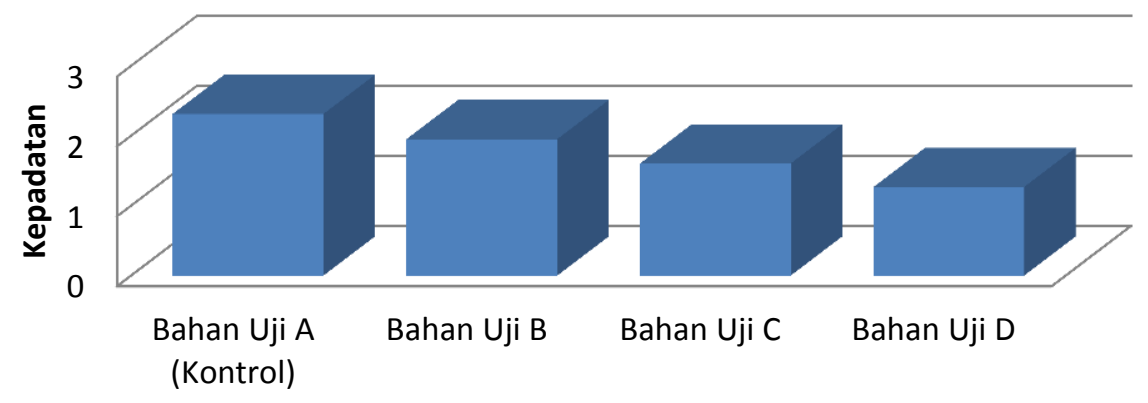

Gambar 8. Grafik Kepadatan Bahan Uji

Menurut SNI No.03-1027-2006 bahwa tepi potongan, permukaan dan bidang potong lembaran harus menunjukkan potongan yang lurus, rata, dan berbentuk empat persegi panjang. Permukaan lembaran harus halus tidak menunjukkan retak-retak atau cacat lainnya. Dari hasil pengamatan tepi potong, permukaan dan bidang potong lembaran, menunjukkan hampir dari semua komposisi hasilnya rata-rata baik, hanya ada satu sisi tepi potong yang kurang rata yaitu pada komposisi 0,2 Serat Polipropilena, sehingga dapat disimpulkan bahwa semakin banyak Serat Polipropilena maka semakin susah untuk meratakan sisi - sisinya, selain itu jika komposisi Serat Polipropilena ditambah atau lebih dari 0,20 maka hasil fiberglass akan jelek dan permukaannya tidak rata.

Pengukuran panjang dan lebar komposisi kontrol yaitu 25,00 cm pada panjang dan 24,90 cm pada lebar (Bahan Uji Lentur), 10,00 cm X 9,9 cm (Bahan Uji Kedap Air) dan 20,00 cm X 10,00 cm (bahan Uji Kepadatan),sedangkan nilai terendah adalah bahan uji D dari komposisi pengggunaan Serat Polipropilena 0,20 Kg yaitu 24,8 cm X 24,8 cm (Bahan Uji Lentur), 9,8 cm X 9,7 cm (Bahan Uji Kedap Air) dan 19,7 X 9,7 cm (bahan Uji Kepadatan). Hasil pengukuran tebal dapat dilihat pada Tabel 8 Menurut SNI No.03-1027-2006 bahwa penyimpangan dari tebal fiberglass maksimal 10\%, dari hasil pengukuran tebal fiberglass menunjukkan nilai 5,83\% terdapat pada Komposisi B Bahan Uji Kepadatan. hasil rata-rata tebal fiberglass dari semua komposisi semuanya baik dalam arti tebal toleransi fiberglass tidak melebihi 10\% dari ketetapan SNI No.03-1027-2006 serat krisotil semen rata. Pengukuran kesikuan selisih antara diagonal tidak bolek lebih dari 0,25\% dari diagonal terpendek, 
dari hasil pengukuran kesikuan fiberglass menunjukkan, hasil rata-rata kesikuan fiberglass dari semua komposisi semuanya baik.

Pengujian kuat lentur dapat rata-rata dari komposisi satu dengan yang lain mengalami peningkatan mulai dari $580,3 \mathrm{~kg} / \mathrm{cm}^{2}, 676,8 \mathrm{~kg} / \mathrm{cm}^{2}, 746,4 \mathrm{~kg} / \mathrm{cm}^{2}$ dan $881,3 \mathrm{~kg} / \mathrm{cm}^{2}$,ini menunjukkan adanya pengaruh banyaknya campuran Serat Polipropilena dalam pembuatan fiberglass, jadi semakin banyak Serat Polipropilena maka semakin kuat. Namun dari hasil pengujian kuat lentur di atas campuran Serat Polipropilena masih rendah dibandingkan dengan campuran serat fiber atau kontrol yaitu sebesar $881,3 \mathrm{~kg} / \mathrm{cm}^{2}$. Kedap air, menunjukkan bahwa baik fiberglass yang pembuatannya memakai bahan campuran serat fiber maupun Serat Polipropilena, tidak terjadi tetesan selama pengujian berlangsung 24 jam. Hasil dan analisis data kedap air pada fiberglass juga menunjukkan bahwa fiberglass yang pembuatannya memakai bahan campuran Serat Polipropilena pada pengujian kedap air memenuhi standart, karena Serat Polipropilena masih terselimuti oleh campuran resin dan katalis sehingga air tidak dapat merembes.

Kepadatan menunjukkan adanya pengaruh penambahan Serat Polipropilena dalam pembuatan fiberglass, karena berat jenis Serat Polipropilena yang lebih ringan dibandingkan serat fiber mengakibatkan semakin banyak penambahan Serat Polipropilena maka berat volume fiberglass, uji kepadatan material dengan menggunakan serat polipropilena yang berlebihan $\left(0,20 \mathrm{~g} / \mathrm{cm}^{2}\right)$ uji kepadatannya menurun hingga 45,14\% dari bahan uji kontrol. Sehingga komposisi D dengan kepadatan $1,27 \mathrm{~g} / \mathrm{cm}^{2}$ tidak layak untuk digunakan sebagai bahan baku untuk meningkatkan mutu produk, karena lebih rendah dari mutu produk yang ditetapkan oleh SNI 03 - 1027 - 2006 Lembaran serat krisotil semen rata.

\section{KESIMPULAN}

Fiberglass yang menggunakan Serat Polipropilena mempunyai kualitas hampir sama dengan yang menggunakan serat fiber. Uji lentur serat fiber sebesar 881,3 $\mathrm{kg} / \mathrm{cm}^{2}$ dan uji lentur serat Polipropilena mencapai $746,4 \mathrm{~kg} / \mathrm{cm}^{2}$. Uji kepadatan material dengan menggunakan serat polipropilena yang berlebihan $\left(0,20 \mathrm{~g} / \mathrm{cm}^{2}\right)$ akan menurunkan kepadatan hingga 45,14\% dari bahan uji kontrol. Sehingga komposisi kepadatannya mencapai $1,27 \mathrm{~g} / \mathrm{cm}^{2}$ dan tidak layak untuk digunakan sebagai bahan baku untuk meningkatkan mutu produk.

\section{DAFTAR PUSTAKA}

D.L. Sanggarang. 2004. Membuat Kerajinan Baerbahan Fiberglass. Kawan Pustaka : Jakarta

Edward G. Nawy, Dr. P.E. 1998.Uji Tekan Beton PT. Refika Aditama : Bandung

G. Takeshi Sato dan N. Sugiarto H. 1983. Menggambar Menurut Standar I. S. O. Pradnya Pratama : Jakarta

Gupta, V.B. and V.K. Kothari . 1997. Manufactured Fibre Technology. Chapman and Hall. London.

Kyung-Jun Chu. Eur. Polym. J. Vol. 34, No. 3/4, pp. 577-580, 1998

Loewenstein, K.L. 1973. The Manufacturing Technology of Continuous Glass Fibers. Elsevier Scientific. New York.

Lubin, George.1975. Handbook of Fiberglass and Advanced Plastic Composites. Robert E. Krieger. Huntingdon NY.

Mohr, J. G. and W. P. Rowe.1978. Fiberglass. Van Nostrand Reindhold. Atlanta. 
R. Kleinschmidt et al. Journal of Molecular Catalysis A: Chemical, 157(2000) 83-90

Riyadi, Slamet. 2010. Manfaat Limbah Bulu Ayam Sebagai Bahan Green Material,(Online),(http://o2indonesia.files.wordpress.com/2010/03/27109029 _uts.pdf, diakses 20 September 2013).

Standar Nasional Indonesia No. 03 - 1027 - 1995. Lembaran Asbes Semen Rata. Dewan Standarisasi Indonesia.

Sugiyono, 2008 Metode penelitian Administrasi .Alpabeta.Bandung

Song et al. Macromol. Symp. 2004, 213, 173-185

Sonikiawan, Irianto. Dkk. 2010. Pemanfaatan Limbah Rambut Salon Sebagai Serat Penguat Pada Roof Fiber Glass Cetak Tembus Sinar, (Online), (http://kemahasiswaan.um.ac.id/wp-content/uploads/2010/04/PKM-GT-10UM-Sonikiawan-Pemanfaatan-Limbah-Rambut-x.pdf, diakses 21 Oktober 2013).

Tim Penyusun. 2011. Pedoman Penulisan Tesis dan Disertasi: Program Pasca Sarjana Universitas Muslim Indonesia. Makassar .

Volf, Milos B.1990.Technical Approach to Glass. Elsevier. New York. 